\title{
Effects of fire on native columnar and globular cacti of Puerto Rico: a case study of El Faro, Cabo Rojo
}

\author{
Roberto Carrera-Martínez ${ }^{1}$, Jorge Ruiz-Arocho ${ }^{1,2}$, Laura Aponte-Díaz ${ }^{1}$, David A. Jenkins ${ }^{3,4}$ and Joseph J. O'Brien ${ }^{5^{*}}$ (D)
}

\begin{abstract}
Background: Many Puerto Rican ecosystems evolved without a regular fire regime. As such, many native plants lack adaptations necessary to survive even low-intensity fires. Human-caused fires are increasing in frequency, in part promoted by the presence of invasive grasses. During the afternoon of 19 February 2014, a wildfire burned a large portion of the dry forest in El Faro Natural Reserve, Cabo Rojo, Puerto Rico. Using a previously monitored population, we documented the mortality and morphological damage on three columnar and semi-epiphytic cactus species (Pilosocereus royenii [L.] Byles \& Rowley, Harrisia portoricensis Britton, and Leptocereus quadricostatus Britton) and one globular species (Melocactus intortus [Mill.] Urb.) in relation to canopy cover and cactus growth strategy.

Results: Our results suggest that $M$. intortus and $H$. portoricensis were more susceptible to fire damage. Cacti growing in areas dominated by grasses and shrubs were significantly more likely to burn than those growing under a closed tree canopy. Apart from L. quadricostatus, cacti that survived at least one year after the fire had lost spines, developed scarring tissue in some or all ribs, and few were able to regrow.
\end{abstract}

Conclusions: Because extensive tissue damage and environmental alterations were observed during the postfire survey, which occurred between 14 to 19 months after the fire, we argue there will be significant delayed mortality and that the mortality estimates presented here are conservative.

Keywords: closed canopy, disturbances, grasses, mortality, refuge, survival

\section{Resumen}

Antecedentes: Muchos ecosistemas de Puerto Rico evolucionaron sin un régimen de fuegos regular. Como consecuencia, a muchas plantas nativas les faltan las adaptaciones necesarias para sobrevivir aún a fuegos de baja severidad. Los incendios causados por humanos han incrementado sus frecuencias, en parte promovidos por la presencia de pastos invasores. Durante la tarde del 19 de febrero de 2014, un incendio quemó una gran parte del bosque seco en la Reserva Natural del Faro, en Cabo Rojo, Puerto Rico. Usando una población relevada previamente, documentamos la mortalidad y daños morfológicos sobre tres especies de cactus (Continued on next page)

\footnotetext{
* Correspondence: joseph.j.obrien@usda.gov

${ }^{5}$ USDA Forest Service, Center for Forest Disturbance Science, 320 Green

Street, Athens, Georgia 30602, USA

Full list of author information is available at the end of the article
}

\section{Springer Open}

(c) The Author(s). 2020 Open Access This article is licensed under a Creative Commons Attribution 4.0 International License, which permits use, sharing, adaptation, distribution and reproduction in any medium or format, as long as you give appropriate credit to the original author(s) and the source, provide a link to the Creative Commons licence, and indicate if changes were made. The images or other third party material in this article are included in the article's Creative Commons licence, unless indicated otherwise in a credit line to the material. If material is not included in the article's Creative Commons licence and your intended use is not permitted by statutory regulation or exceeds the permitted use, you will need to obtain permission directly from the copyright holder. To view a copy of this licence, visit http://creativecommons.org/licenses/by/4.0/. 


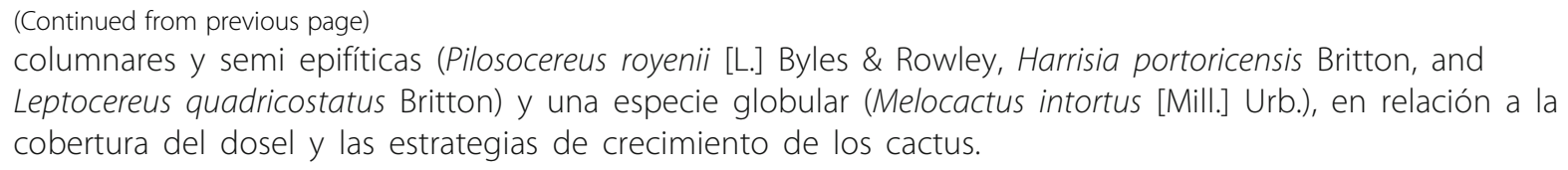

Resultados: Nuestros resultados sugieren que $M$. intortus y $H$. portoricensis fueron más susceptibles al daño por fuego. Los cactus creciendo en áreas dominadas por pastos eran significativamente más probable que se quemaran que aquellos creciendo debajo del dosel cerrado de árboles. Aparte de L. quadricostatus, los cactus que sobrevivieron al menos un año después del fuego habían perdido las espinas, desarrollado tejido chamuscado en algunas o todas sus nervaduras, y unos pocos fueron capaces de rebrotar.

Conclusiones: Dado el extensivo daño y alteraciones ambientales que fueron observadas durante el relevamiento post-fuego, que ocurrió entre 14 y 19 meses posteriores al incendio, argüimos que habrá una significativa mortalidad retrasada y que las estimaciones aquí presentadas son conservadoras.

\section{Introduction}

Fire influences virtually all terrestrial ecosystems and, in many cases, regular fires are needed to maintain community structure, productivity, and biodiversity (Bond and Keeley 2005). However, the alteration of a fire regime can also radically alter ecosystem function and composition resulting in habitat loss (Janzen 1988; Miles et al. 2006; Jolly et al. 2015; Monmany et al. 2017). In many ecosystems on the island of Puerto Rico, fires are almost exclusively the direct or indirect result of recent human activity (Burney et al. 1994; Méndez-Tejeda et al. 2015; Monmany et al. 2017) and cause severe impacts on ecosystems and negatively affect public health (Aide et al. 1995, 2000; Grau et al. 2003; Miles et al. 2006; Thaxton et al. 2012b; Wolfe et al. 2014; Jolly et al. 2015). For example, fire delayed the recovery of forests in abandoned agricultural fields and landslides by promoting the presence of grasses and delaying colonization by woody species (Walker and Boneta 1995; Grau et al. 2003).

Tropical dry forests are especially threatened by an increased fire frequency that promotes the persistence of invasive species (Janzen 1988; Miles et al. 2006). The dry forests of Puerto Rico are located in the south and southwestern lowland regions of the island (Murphy and Lugo 1995; Murphy et al. 1995) and are generally considered biological hotspots (Monsegur Rivera 2009). They are also susceptible to the deleterious effects of fire. In these ecosystems, native woody plant species lack the morphological adaptations necessary to survive even low-intensity fire events (Wolfe et al. 2014). Furthermore, fires in the dry forests of Puerto Rico can also promote the invasion of exotic fire-promoting grasses like Megathyrsus maximus (Jacq.) B.K. Simon \& S.W.L. Jacobs and Cenchrus ciliaris L., suppressing native grasses (Thaxton et al. 2012b). Megathyrsus maximus invasions in Puerto Rico are associated with the decline of native flora diversity and richness (Rojas-Sandoval and Meléndez-Ackerman 2012; Rojas-Sandoval et al. 2012; García-Cancel and Thaxton 2018). In particular, $M$. maximus on Mona Island could drive some populations of the endemic columnar cacti Harrisia portoricensis Britton to extinction in less than 60 years (Rojas-Sandoval et al. 2016). In addition, when compared to invasive grasses, Puerto Rican native grasses generate limited fuels, generally not enough to naturally combust (Thaxton et al. 2012b).

Tropical dry forests in Puerto Rico are home to 24 species of cactus, of which five are native columnar, semi-epiphytic, or globular cactus inhabiting the main island (Liogier 1994; Carrera-Martínez et al. 2018). These dry forests are more likely to ignite under normal climatic conditions than tropical wet or rain forests (Monmany et al. 2017) and, at least in Puerto Rico, fire frequency in these forests is expected to increase (Van Beusekom et al. 2018). Cactus species are historically considered fire intolerant (Benson and Walkington 1965), with average mortality considerably higher than other succulent species (Thomas 1991). Previous studies on Central and North American cactus taxa have shown mixed post-wildfire cactus survival varying from $>90 \%$ to $<30 \%$ within the same species (Benson and Walkington 1965; Bunting et al. 1980; Thomas 1991, 2006; Thomas and Goodson 1992; Vermeire and Roth 2011; Thomas et al. 2017). This is likely due to the inherent variability in wildfire behavior. However, no studies have focused on the effects of fires on Puerto Rican cacti, even though they are generally referred to as keystone species (Valiente-Banuet et al. 2002; Carrera-Martínez et al. 2018), and at least two species (H. portoricensis and Leptocereus quadricostatus Britton) are considered to be endangered (US Fish and Wildlife Services1990; Gann and Taylor 2013). Protections were extended to $H$. portoricensis after it was extirpated from the main island (US Fish and Wildlife Service 1990), and it has been recently reintroduced in Los Morrillos Peninsula in southwestern Cabo Rojo (O. Monsegur, US Fish and Wildlife Service, Puerto Rico, USA, personal communication).

The objective of this study was to document the impact of the El Faro fire on four cactus species (Pilosocereus 
royenii [L.] Byles \& Rowley, Melocactus intortus [Miller] Urban, $L$. quadricostatus and $H$. portoricensis). Here, we: (1) provide observations on the morphological consequences of fire injuries; (2) confirm the negative effects of fire on cacti survival; (3) determine which habitats (closed canopy versus grass-dominated open canopy) had the highest cacti mortality; and (4) determine if morphology (globular versus columnar cacti) affected post-fire mortality. We expected to observe a higher mortality on areas dominated by grasses and shrubs than under closed canopies, as the latter have lower fuel reserves (Thaxton et al. 2012b) and may function as refugia for succulents (Thomas 1991). Additionally, we expected to detect a higher mortality rate for globular cacti (M. intortus) than the columnar cacti species, due to their preference for bare soils and open canopy areas (Carrera-Martínez et al. 2018). Because this is an observational study as a result of an unforeseen event, we do not aim to link or distinguish between direct (e.g., burned cactus) or indirect interactions (e.g., erosion, habitat, and microclimate change) on cacti mortality as a result of fire damage, although we recognize the importance of these parameters in the survivorship and restoration of the population.

\section{Methods}

\section{Study site}

Los Morrillos Peninsula is a historic and natural reserve located in the most southwestern point of the island of Puerto Rico, in the municipality of Cabo Rojo (latitude: $17.9349^{\circ}$, longitude: $\left.-67.1943^{\circ}\right)$. It is divided into two mostly isolated land masses that are protected by the Puerto Rican government as part of the Boquerón State Forest. The most western land mass includes the Los Morrillos Lighthouse (known as El Faro, the name we use herein to refer to Los Morrillos Peninsula), which was built in the 1880 s by the Spanish government. Before the fire event, the El Faro section seemed to be dominated by native flora, with Uniola virgata (Poir.) Griseb. as a dominant grass. Croton discolor Willd., Cocoloba diversifolia Jacq., Melochia tomentosa L., and Lantana L. sp. appeared to be the most abundant shrubs, and the somewhat patchy tree community included different life stages of Exostema caribaeum (Jacq.) Schult., Pisonia aldida (Heimerl) Britton ex Standl., Tabebuia heterophylla (DC.) Britton, and Bucida buceras L. The fire-promoting invasive grass Cenchrus ciliaris was abundant, and M. maximus was also present, but at an apparent lower frequency (personal observations). Cacti flora was dominated by Pilosocereus royenii (L.) Byles \& Rowley and Melocactus intortus (Mill) Urb., while Leptocereus quadricostatus, Opuntia triacantha (Willd.), and Opuntia cf. stricta (Haw.) Haw. were present but not abundant. The endemic Harrisia portoricensis Britt. was reintroduced onto the peninsula with the planting of close to 40 juveniles (O. Monsegur, personal communication). The site soils are mostly shallow, with many patches of exposed limestone typical of coastal dry forests. For more details on Puerto Rican dry forests, including the El Faro site, refer to Murphy and Lugo (1995) and Murphy et al. (1995), and for Puerto Rican columnar cacti habitat preferences, refer to Carrera-Martínez et al. (2018).

\section{Wildfire}

The wildfire at El Faro occurred on the afternoon of 19 February of 2014 and burned under extreme fire weather conditions. The afternoon mean wind speeds on the day of the burn were 29 to $35 \mathrm{~km} \mathrm{hr}^{-1}$ out of the east, with gusts up to $58 \mathrm{~km} \mathrm{hr}^{-1}$; relative humidity was $48 \%$, the air temperature was approximately $30{ }^{\circ} \mathrm{C}$; and it had been 20 days since the last measurable precipitation. Fuels in the area consisted of cured grasses with scattered shrubs interspersed with areas of sparse fuels under small trees and over scattered exposed rock (Fig. 1). The fire burned approximately 11 ha within the reserve before firefighters were able to extinguish it (Fig. 1). The cause of the fire is unknown but was almost certainly human caused as there were no other plausible ignition sources and the site had many visitors on the day of the fire. While we lack direct observations of the fire, we can infer that it was likely intense and fast moving due to the fuels and weather conditions. Heat exposure to several of the cacti was indicated by melted aluminum tags. However, the fire consumed only the finest fuel particles in most of the area, leaving even small-diameter woody stems intact.

\section{Surveys}

The El Faro site was initially selected and monitored for another study on the effects of Hypogeococcus Rau sp. (Hemiptera: Pseudococcidae) cacti infestation (CarreraMartínez et al. 2015, 2019). As such, we refer to pre-fire surveys as those conducted as part of that project but which were not explicitly designed to measure the impact of fire. Sampling occurred between March and May 2013, and included a total of 308 specimens of four species: $P$. royenii (161 specimens), adults $M$. intortus (126 specimens), $H$. portoricensis (18 specimens), and $L$. quadricostatus (3 specimens or stem clusters) (Carrera-Martínez et al. 2015, 2018; Carrera-Martínez et al. 2019). Prior to the fire, Carrera-Martínez et al. (2015) and CarreraMartínez et al. (2019) tagged all cacti and neighboring plants (within $\sim 1 \mathrm{~m}$ distance) were identified at least to functional groups (grasses, shrubs, and trees) and classified in terms of canopy habitat as closed (e.g., cactus found growing under trees) or open (e.g., cactus found in gaps between trees) canopy habitat. A set of Global Positioning System coordinates was also obtained for each cactus specimen. Each cactus specimen was revisited between April 

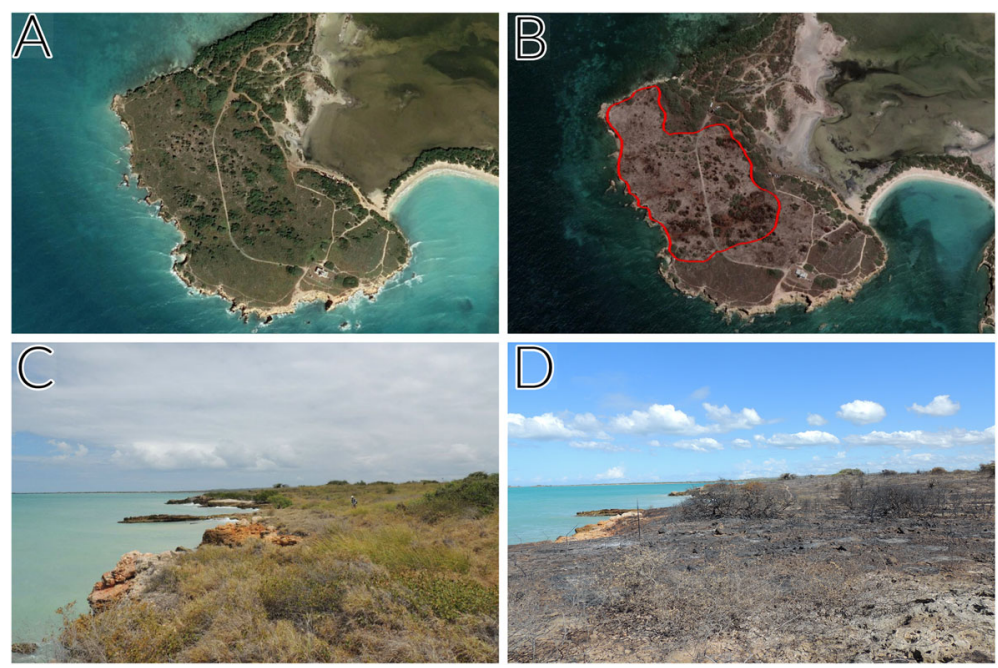

Fig. 1 Images from El Faro, Puerto Rico, of entire burn (A) pre fire in January 2014, (B) post fire in January 2015, (C) pre fire in April 2013, and (D) post-fire conditions in February 2014. The fuels seen in (C) are representative of the burned area. The red outline in (B) represents the fire perimeter. (D) highlights that the fire consumed only the finest fuels such as grasses. Photos by R. Carrera Martinez

and November 2015 to determine the survival of each specimen after the fire of February 2014. However, completely mature cacti in the center of the burned area were never found during the revisits and presumed dead, as no living vegetation other than grasses were observed at this location. Cacti were resurveyed post fire and observations taken on survival, damage to ribs or cephalia, spine condition, the presence of any new growth, and nearby habitat conditions.

\section{Statistical analyses}

Because of the rarity of $H$. portoricensis and L. quadricostatus in our survey, we analyzed the data in two ways: (1) by grouping these species with $P$. royenii by growth form (columnar cacti); and then (2) by excluding $H$. portoricensis and L. quadricostatus, as these species appear to have different habitat preferences from that of $M$. intortus and P. royenii (Carrera-Martínez et al. 2018). To determine the direct or indirect effects of burning on the survival of each cactus specimen, we applied a binomial logistic regression using habitat preferences (open versus closed canopy) and cactus growth strategy (globular versus columnar) as explanatory variables: (Mortality Burned + Canopy Cover + Growth Strategy + [Canopy Cover $\times$ Burned $]+$ [Growth Strategy $\times$ Burned] + [Growth Strategy $\times$ Canopy Cover]). To explore fire effects on cacti in gaps, we applied another binomial logistic model: (Burned Canopy Cover + Growth Strategy + [Canopy Cover $\times$ Growth Strategy]). All statistical analyses were performed in Rstudio version 3.3.1 ( $R$ Core Team 2016).

\section{Results}

Of the 308 tagged cacti, 220 (71.4\%) were burned, of which 154 (50.0\%) were dead in the 2015 census. About $58.4 \%$ of P. royenii (94 of the 161 recorded), $86.5 \%$ of $M$. intortus (109 of the 126 recorded), $83.3 \%$ of $H$. portoricensis (15 of the 18 recorded), and $66.7 \%$ of L. quadricostatus stem clusters ( 2 of the 3 recorded) were burned. $M$. intortus had the highest mortality (86 specimens, or $68.3 \%$ of the species total), followed by $H$. portoricensis (12 or $66.7 \%$ ), and P. royenii (56 or $34.8 \%$ ). Both groups of burned $L$. quadricostatus survived (Fig. 2). Only four cacti (two $M$. intortus, one $H$. portoricensis, and one $P$. royenii) died without evidence of being burned, and their deaths were attributed to Hypogeococcus sp. infestation (see Carrera-Martínez et al. 2019).

Mortality of the cacti was strongly associated with the absence of a canopy and burning (Fig. 2), whether Harrisia and Leptocereus were included in the model or not. A burned cactus was 60 to 70 times more likely to die than an unburned cactus $(P<0.001$; Table 1 , Fig. 2$)$. While the data showed that Melocactus intortus was 13 times more likely to die when burned compared to $P$. royenii, these results were not significant, even when $L$. quadricostatus and $H$. portoricensis were excluded from the analysis $(P>0.05$, Table 1$)$. Burning was strongly correlated with the absence of a canopy as cacti were almost five times more likely to have some fire damage when growing in open canopy compared to those growing in closed canopy $(P<0.001$, Table 2$)$, whether Harrisia and Leptocereus were included or not. Although not significant $(P>0.05)$, Melocactus intortus was 2.5 times more likely to be burned compared to all 


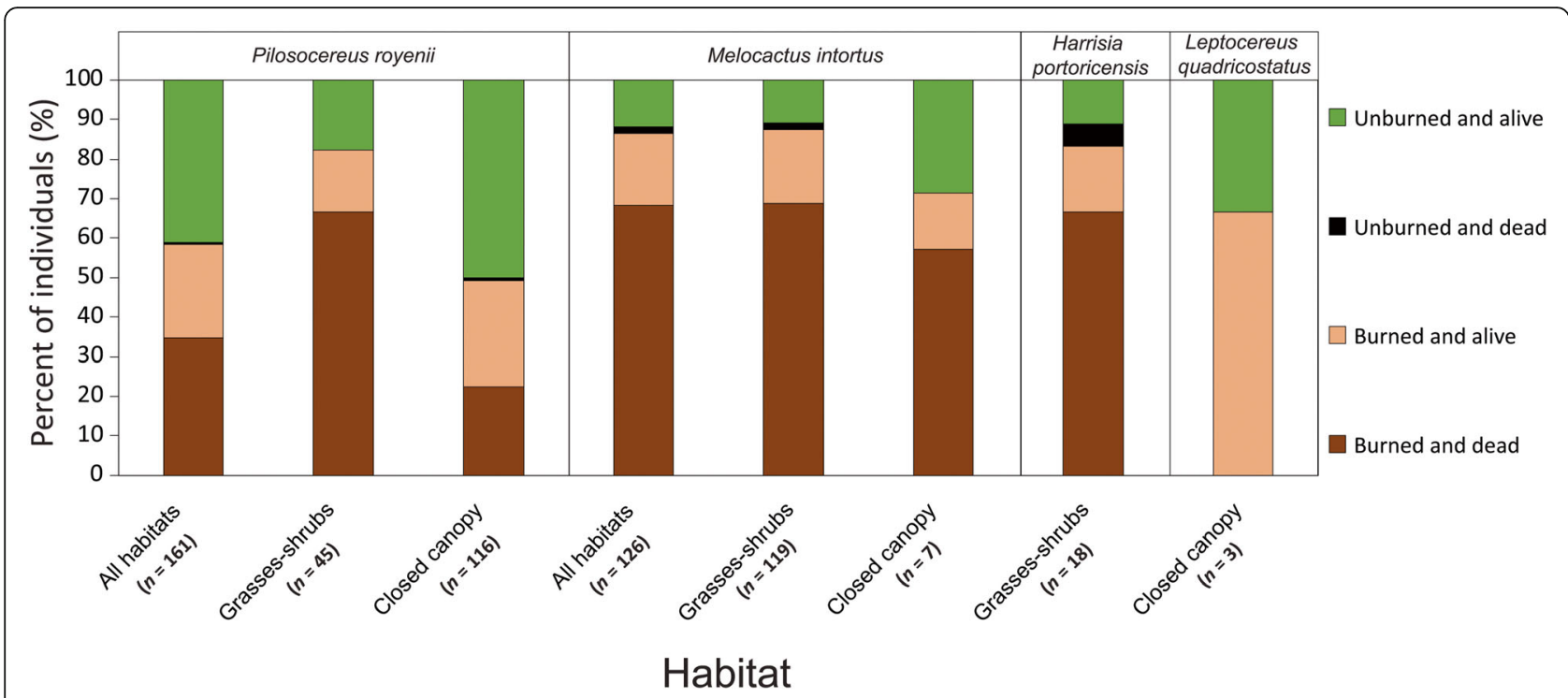

Fig. 2 Proportions of burned and unburned cacti and survival rates of Pilosocereus royenii, Melocactus intortus, Harrisia portoricensis, and Leptocereus quadricostatus divided with respect to habitat type (grasses-shrubs, closed canopy, all habitats), from data collected after the wildfire at El Faro, Puerto Rico, in 2014 and 2015. Harrisia portoricensis and L. quadricostatus were found only in grasses-shrubs and closed canopy, respectively

columnar species and 1.1 times more likely to be burned when L. quadrcostatus and $H$. portoricensis were excluded from the analysis (Table 2).

Fire damage to cacti was characterized by most of the distal ribs and spines being burned. In the case of severe burning, specimens of $P$. royenii would lose turgor and have a gelatinous texture. When an old and tall $P$. royenii was burned, the burned area would be limited to the main trunk and most distal branches, while the more internal, central and taller branches would remain unburned (Fig. 3). However, in many cases where this happened, the damage suffered by the main trunk was severe enough to kill it. In the case of $M$. intortus, all ribs and the cephalium (or inflorescence) were also damaged, and in many cases completely lost (Fig. 4). At least ten individuals (22.2\%) of M. intortus were able to regrow at least a second branch or cephalium, but this was not commonly observed at the time of the survey (Fig. 4). The two clusters of $L$. quadricostatus were

Table 1 Results of the logistic regressions of cactus mortality, with burn, canopy type, and growth strategy as explanatory variables on data collected in 2014-2015 at El Faro, Puerto Rico. The analysis was conducted with and without Leptocereus quadricostatus and Harrisia portoricensis data. Odds ratio is the probability of being killed by the fire versus surviving the fire (e.g., burned cacti were more than 62 times as likely to die as unburned cacti); Z-value is the regression coefficient divided by its standard error; $P$-value represents the probability of a Type I error

\begin{tabular}{|c|c|c|c|}
\hline Parameter & Odds ratio $( \pm$ SE) & Z-value & $P$-value \\
\hline Intercept & $0.016(2.75)$ & -4.086 & $<0.001$ \\
\hline Burned & $61.868(2.83)$ & 3.833 & $<0.001$ \\
\hline Open Canopy (Grasses and shrubs) & $6.495(4.01)$ & 1.342 & 0.180 \\
\hline Globular Cactus & $1.428(3.46)$ & 0.287 & 0.774 \\
\hline Burned x Open Canopy & $0.623(4.26)$ & -0.328 & 0.743 \\
\hline Burned x Globular Cactus & $0.809(3.67)$ & -0.162 & 0.870 \\
\hline \multicolumn{4}{|c|}{ Without Leptocereus quadricostatus and Harrisia portoricencis } \\
\hline Intercept & $0.012(3.03)$ & -3.963 & $<0.001$ \\
\hline Burned & $69.200(3.09)$ & 3.743 & $<0.001$ \\
\hline Open Canopy (Grasses and shrubs) & $2.924(5.31)$ & 0.642 & 0.521 \\
\hline Globular Cactus & $13.131(5.37)$ & 1.533 & 0.125 \\
\hline Burned x Open Canopy & $1.632(5.37)$ & 0.292 & 0.770 \\
\hline Burned x Globular Cactus & $0.259(5.21)$ & -0.819 & 0.413 \\
\hline
\end{tabular}


Table 2 Results of the logistic regressions predicting probability of a cactus to burn, canopy type and growth strategy as explanatory variables. The analysis was conducted with and without Leptocereus quadricostatus and Harrisia portoricensis data. Data were collected in 2014-2015 at El Faro, Puerto Rico. Odds ratio is the probability of being killed by the fire versus surviving the fire (e.g., burned cacti were more than 62 times as likely to die as unburned cacti); Z-value is the regression coefficient divided by its standard error; $P$-value represents the probability of a Type I error

\begin{tabular}{lrrr}
\hline Parameter & Odds ratio $( \pm$ SE) & Z-value & $P$-value \\
\hline Intercept & $0.983(1.20)$ & -0.092 & 0.927 \\
Open Canopy (Grasses and shrubs) & $4.807(1.46)$ & 4.141 & $<0.001$ \\
Globular Cactus & $2.542(2.39)$ & 1.089 & 0.276 \\
Open Canopy x Globular Cactus & $0.577(2.61)$ & -0.574 & 0.566
\end{tabular}

Without Leptocereus quadricostatus and Harrisia portoricencis

Intercept

Open Canopy (Grasses and shrubs)

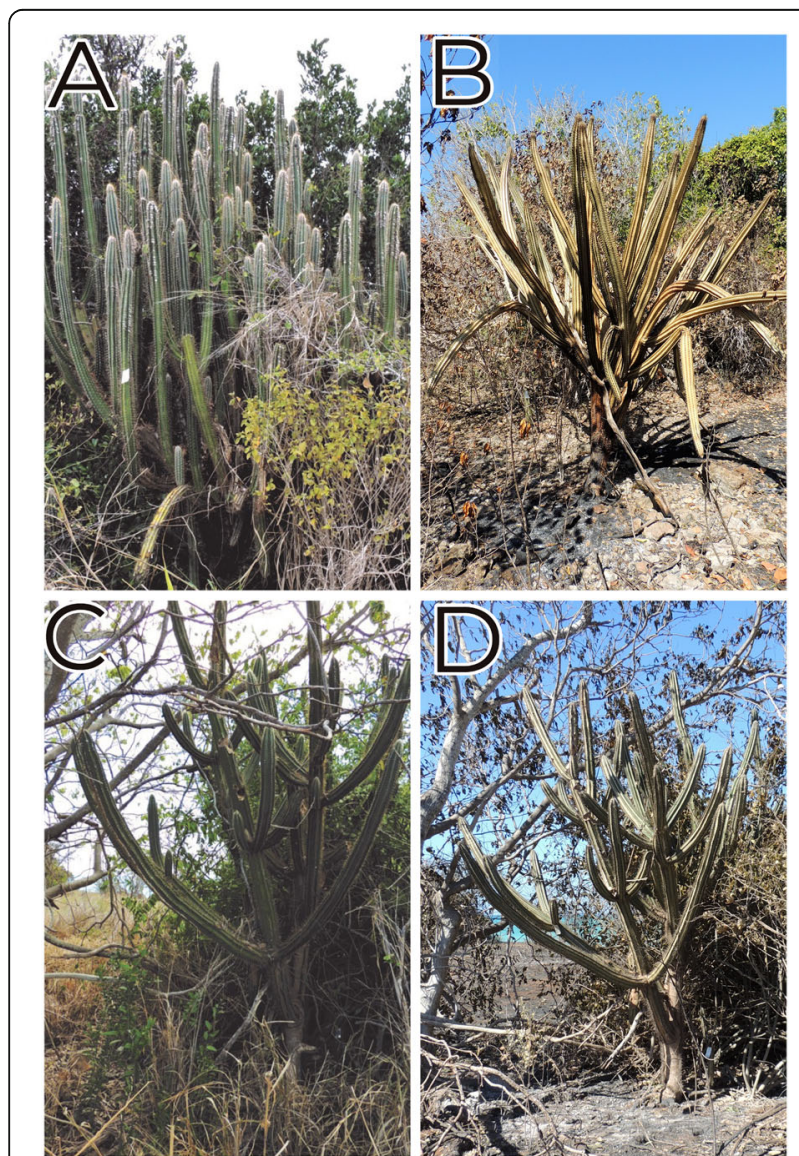

Fig. 3 Examples of Pilosocereus royenii (A, C) pre fire in April 2013, and (B, D) post fire in February 2014, in El Faro, Puerto Rico. Photos by R. Carrera-Martínez completely burned and top-killed, but at the time of the final survey, many of these individual branches were resprouting from the base of the burned trunk. All but two $H$. portoricencis were completely burned and reduced to a spineless stem, almost unrecognizable (Fig. 5).

\section{Discussion}

Cacti located in a burned site were almost 62 times more likely to have died one year after the fire. Also, cacti located in the open were more likely to burn and die than those found under closed canopies. Although M. intortus had a relatively higher probability to be burned and die than the columnar species, this effect was not significantly different. Melocactus intortus was abundant on the bare calcic rocks with limited shrubs and higher grass cover, while $P$. royenii was naturally present at both closed and open canopy habitats (Carrera-Martínez et al. 2018). Unfortunately, we cannot discriminate between direct and indirect fire, but nonetheless, it is likely that both mechanisms, together with cactus life history strategies, explain their mortality in our study (Thomas 1991). Closed canopy forests reduce growth of the invasive fire-promoting grasses found on the site, thus reducing fuels (Thaxton et al. 2012b), and can create fire refugia for succulents (Thomas 1991). The invasive grasses are commonly found in bare soils together with $M$. intortus, increasing the risk of fire damage, while $P$. royenii can be found in fuel-free refuges within the woody vegetation.

Different cactus habitat preferences and growth strategies may explain the effects seen in our second model, in which $M$. intortus was more likely to be burned than P. royenii (Table 2). Melocactus intortus is much shorter than $P$. royenii, which also exposes it and its apical meristem to more fire damage than $P$. royenii. Failure to protect the apical meristem tissue during a wildfire usually 

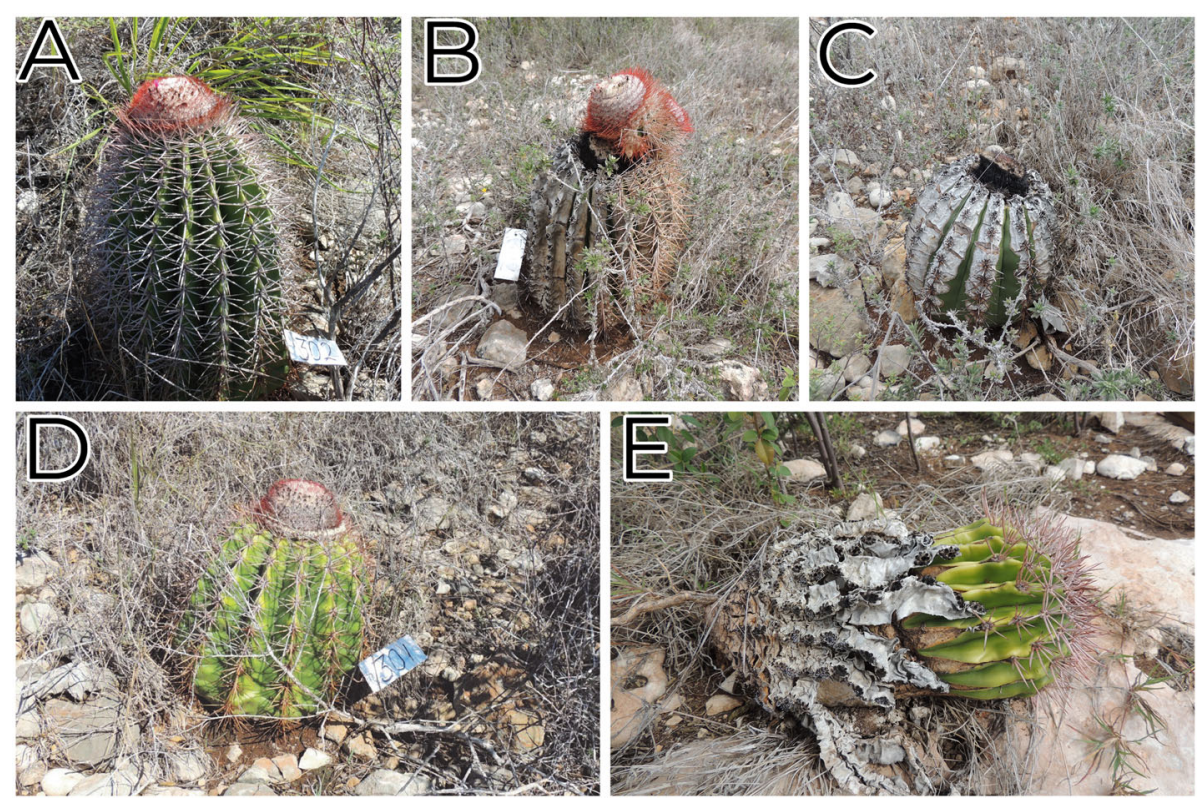

Fig. 4 Melocactus intortus (A, D) pre fire in April 2013, and (B, C, E) post fire in November 2015: (B) burned ribs and damage to cephalium and branch regrowth; (C) fire damage with no branching or regrowth; $(\mathbf{E})$ heavily damaged specimen with apical growth. Photos taken at El Faro, Puerto Rico, by R. Carrera-Martínez

directly results in death (Thomas 1991; Thomas and Goodson 1992).

Melocactus mortality in this study should be regarded as conservative estimates, as some specimens had most or all of their ribs completely burned (Fig. 3). This may have limited or eliminated their capacity to recover, as the auxiliary buds are located at the spiny node rows in each rib. If all auxiliary buds were destroyed during the fire, then the cactus would be unable to recover from the injuries and eventually die. This delayed mortality in burned cactus and succulent species has been reported for Central and North American arid ecosystems (Thomas 1991; Thomas and Goodson 1992), with long-term consequences (Thomas 2006).

$H$. portoricensis is the least fire-tolerant species as its mortality was highest, with only two burned specimens surviving. Additionally, like L. quadricostatus, Harrisia stems are thin, providing little to no resistance to fire damage (Fig. 4). Differing from L. quadricostatus, $H$. portoricensis was not able to regrow during our study. The regrowth

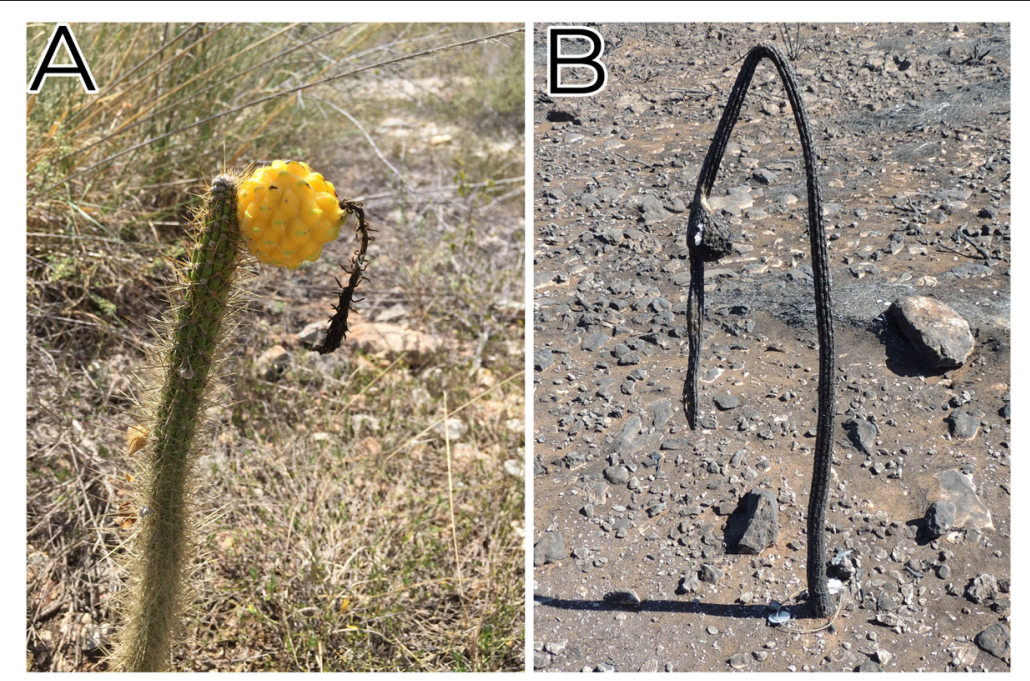

Fig. 5 Stems of Harrisia portoricensis (A) unburned in 2013, and (B) burned, dead specimen in 2014. Photos taken at El Faro, Puerto Rico, by R. Carrera-Martínez 
ability of $L$. quadricostatus might be an adaptation to rely more on clonal reproduction and to inhabit disturbed areas, rather than a fire tolerance. A similar post-fire rootresprouting response has been seen in some deciduous succulents and a few Opuntia species, depending on fire intensity and the degree of exposure (Thomas 1991).

Puerto Rican forests evolved with infrequent fire as have many other dry forest ecosystems, with nearly all fires directly or indirectly associated with anthropogenic ignitions (Burney et al. 1994; Méndez-Tejeda et al. 2015; Monmany et al. 2017). Native grasses in sites like El Faro produce too little fuel to support fires (Thaxton et al. 2012b). Because of this, many native plants lack the morphological adaptations to survive fire (Wolfe et al. 2014). With the introduction of more frequent ignitions through a variety of human activities, combined with the presence of introduced fire-adapted and fire-promoting grasses, the recovery of native vegetation in disturbed areas is inhibited (D'Antonio and Vitousek 1992; Ellsworth et al. 2013, 2014). This has the potential to limit the regeneration or restoration of natural forests in the area (Janzen 1988; Aide et al. 2000), resulting in species loss. Furthermore, fire frequencies are higher in the southern region of the island dominated by dry forests, and, in general, are projected to increase in the future (Monmany et al. 2017). Given that many of the species are fire sensitive, high fire frequencies could potentially drive the ecosystem to a grass-dominated state with a concomitant loss of plant diversity (Hoffmann et al. 2009).

A commonly suggested habitat management strategy to mitigate wildfires and invasive grasses is to promote regeneration of secondary forests (e.g., Weaver and Schwagerl 2008; Wolfe and Van Bloem 2012). Invasive grasses are not able to dominate the understory of a closed canopy forest, which reduces the fuels and limits fire spread (Santiago-García et al. 2008; Weaver and Schwagerl 2008; Thaxton et al. 2012b; Wolfe and Van Bloem 2012). Similar effects were observed in a Hawaiian dry forest after planting three woody bushes, restoring functionality to the ecosystem (Ammondt and Litton 2012; Ammondt et al. 2013). However, regenerating forested habitat may not be convenient for the establishment of Stenocereus fimbriatus (Lam) Lourteig, M. intortus and $H$. portoricensis (the former is a species of conservational concern), as these species prefer open habitats or shrublands (Rojas-Sandoval and Meléndez-Ackerman 2012; RojasSandoval et al. 2016; Carrera-Martínez et al. 2018).

Indeed, conservation, regeneration, and restoration of the Puerto Rican dry forests after a fire event is not a simple task and deserves more attention in future research. Fire-induced changes in the ecosystem may also have lasting effects on cactus populations (Thomas 2006). Because our research was not intended to study the effects of fires in cactus species, our study did not track the fate of juveniles and seedlings of $P$. royenii and $M$. intortus. Cactus seedlings and juvenile stages are important for population maintenance and conservation (Valiente-Banuet et al. 2002), and future research should focus on these life stages during and after a fire event. For our data, we cannot determine if the fire was directly responsible for observed cactus mortality (e.g., through tissue damage, meristem death), or if cactus mortality was the result of an indirect effect of fires in the ecosystem (e.g., erosion, higher exposure to solar irradiation, microclimate changes, pathogen infection). Nonetheless, we observed a significant increase in mortality on cacti that were located on burned areas (Fig. 3) and observed much direct damage attributable to fire. Fires ignited by lightning in Puerto Rican forests are rare (Burney et al. 1994; Méndez-Tejeda et al. 2015; Monmany et al. 2017), and native flora lack the necessary adaptations to survive such disturbances (Wolfe et al. 2014). These fire events can significantly delay natural succession (Walker and Boneta 1995; Grau et al. 2003) and facilitate the invasion of fire-promoting grasses (Thaxton et al. 2012b), which also has negative effects on native biodiversity (Thaxton et al. 2012a; Rojas-Sandoval and Meléndez-Ackerman 2012; Moreno et al. 2014; Rojas-Sandoval et al. 2016; García-Cancel and Thaxton 2018). Our results, combined with the previously cited literature, confirm the negative effects of fire on the conservation of Puerto Rican cactus species and tropical dry forests.

\section{Acknowledgements \\ This work was possible due to help in the field provided by W. Plaza-Muñiz, J.G. García-Cancel, S. Rosado, C.O. Martínez-Almodóvar, A. Lorenzo-Ramos, J. Seguí, R. McPhail, and C. Millan. We are also grateful to O. Díaz, O. Monsegur, and C. Casanova for providing additional information on the area, and to C. M. Vicéns-Cardona for improving the Spanish abstract. Financial support was provided by C.O. Martínez-Almodóvar and R.R. Carrera-Montalvo.}

\section{Authors' contributions}

RCM: original study design, data collection and curation, statistical analyses, manuscript preparation and editing. JRA: original study design, data collection, manuscript editing. LAD: original study design, data collection, manuscript editing. DAJ: original study design, data collection, manuscript editing. JJO'B: statistical analyses, manuscript editing. The author(s) read and approved the final manuscript.

\section{Funding}

This research was funded in part by the USDA Forest Service Southern Research Station.

\section{Availability of data and materials}

The datasets used or analyzed during the current study will be made available upon reasonable request.

Ethics approval and consent to participate Not applicable.

Consent for publication

Not applicable.

\section{Competing interests}

The authors declare that they have no competing interests.

\section{Author details}

${ }^{1}$ University of Puerto Rico, Mayagüez Campus, Call Box 9000, Mayagüez, Puerto Rico 00681-9000, USA. ²Department of Plant and Soil Science, 
University of Vermont, Room 117 Jeffords Hall, 63 Carrigan Drive, Burlington, Vermont 05405, USA. ${ }^{3}$ USDA-ARS Tropical Agriculture Research Station, 2200 P.A. Campos Avenue, Suite 201, Mayagüez, Puerto Rico 00680, USA. ${ }^{4}$ South Carolina Forestry Commission, 5500 Broad River Road, Columbia, South Carolina 29212, USA. ${ }^{5}$ USDA Forest Service, Center for Forest Disturbance Science, 320 Green Street, Athens, Georgia 30602, USA.

\section{Received: 28 January 2020 Accepted: 10 May 2020}

\section{Published online: 16 June 2020}

\section{References}

Aide, T.M., J.K. Zimmerman, L. Herrera, M. Rosario, and M. Serrano. 1995. Forest recovery in abandoned tropical pastures in Puerto Rico. Forest Ecology and Management 77 (1): 77-86 https://doi.org/10.1016/0378-1127(95)03576-V.

Aide, T.M., J.K. Zimmerman, J.B. Pascarella, L. Rivera, and H. Marcano-Vega. 2000. Forest regeneration in a chronosequence of tropical abandoned pastures: implications for restoration ecology. Restoration Ecology 8 (4): 328-338 https://doi.org/10.1046/j.1526-100x.2000.80048.x.

Ammondt, S.A., and C.M. Litton. 2012. Competition between native Hawaiian plants and the invasive grass Megathyrsus maximus: implications of functional diversity for ecological restoration. Restoration Ecology 20 (5): 638649 https://doi.org/10.1111/j.1526-100X.2011.00806.x.

Ammondt, S.A., C.M. Litton, L.M. Ellsworth, and J.K. Leary. 2013. Restoration of native plant communities in a Hawaiian dry lowland ecosystem dominated by the invasive grass Megathyrsus maximus. Applied Vegetation Science 16 (1): 29-39 https://doi.org/10.1111/j.1654-109X.2012.01208.x.

Benson, L., and D.L. Walkington. 1965. The southern Californian prickly pearsinvasion, adulteration, and trial-by-fire. Annals of the Missouri Botanical Garden 52 (3): 262-273 https://doi.org/10.2307/2394792.

Bond WJ, Keeley JE. 2005. Fire as a global 'herbivore': the ecology and evolution of flammable ecosystems. Trends Ecology and Evolution 20 (7): 387-394. https://doi.org/10.1016/j.tree.2005.04.025.

Bunting, S.C., H.A. Wright, and L.F. Neuenschwander. 1980. Long-term effects of fire on cactus in the southern mixed prairie of Texas. Journal of Range Management 33 (2): 85-88 https://doi.org/10.2307/3898415.

Burney, D.A., L.P. Burney, and R.D. MacPhee. 1994. Holocene charcoal stratigraphy from Laguna Tortuguero, Puerto Rico, and the timing of human arrival on the island. Journal of Archaeological Science 21 (2): 273-281 https://doi.org/ 10.1006/jasc.1994.1027.

Carrera-Martínez, R., L. Aponte-Díaz, J. Ruiz-Arocho, and D.A. Jenkins. 2015. Symptomatology of infestation by Hypogeococcus pungens: Contrasts between hosts species. Haseltonia 21: 14-18 https://doi.org/10.2985/026.021.0104.

Carrera-Martínez, R., L. Aponte-Díaz, J. Ruiz-Arocho, A. Lorenzo-Ramos, and D.A. Jenkins. 2019. The effects of the invasive Harrisia cactus mealybug (Hypogeococcus sp.) and exotic lianas (Jasminum fluminense) on Puerto Rican native cacti survival and reproduction. Biological Invasions 00: 1-16 https://doi.org/10.1007/s10530-019-02046-1.

Carrera-Martínez, R., J. Ruiz-Arocho, L. Aponte-Díaz, and D.A. Jenkins. 2018. Natural history notes for the columnar, globular and semi-epiphytic cacti species from Puerto Rico. Haseltonia 24: 16-27 https://doi.org/10.2985/026.024.0104.

D'Antonio, C.M., and P.M. Vitousek. 1992. Biological invasions by exotic grasses, the grass/fire cycle, and global change. Annual Review of Ecology and Systematics 23: 63-87 https://doi.org/10.1146/annurev.es.23.110192.000431.

Ellsworth, L.M., C.M. Litton, A.P. Dale, and T. Miura. 2014. Invasive grasses change landscape structure and fire behavior in Hawaii. Applied Vegetation Science 17 (4): 680-689 https://doi.org/10.1111/avsc.12110.

Ellsworth, L.M., C.M. Litton, A.D. Taylor, and J.B. Kauffman. 2013. Spatial and temporal variability of guinea grass (Megathyrsus maximus) fuel loads and moisture on Oahu, Hawaii. International Journal of Wildland Fire 22 (8): 10831092 https://doi.org/10.1071/WF12051.

Gann GD, Taylor, NP. 2013. Leptocereus quadricostatus. The IUCN Red List of Threatened Species. Version 2015.2. www.iucnredlist.org. Downloaded on 19 August 2015

García-Cancel, J.G., and J.M. Thaxton. 2018. Location near grass patches influences Establishment of native woody species in a Puerto Rican subtropical dry forest. Caribbean Naturalist 51: 1-13.

Grau, H.R., T.M. Aide, J.K. Zimmerman, J.R. Thomlinson, E. Helmer, and X. Zou. 2003. The ecological consequences of socioeconomic and land-use changes in postagriculture Puerto Rico. AlBS Bulletin 53 (12): 1159-1168 https://doi. org/10.1641/0006-3568(2003)053[1159,TECOSA]2.0.CO;2.
Hoffmann, W.A., R. Adasme, M. Haridasan, M.T. de Carvalho, E.L. Geiger, M.A. Pereira, S.G. Gotsch, and A.C. Franco. 2009. Tree topkill, not mortality, governs the dynamics of savanna-forest boundaries under frequent fire in central Brazil. Ecology 90 (5): 1326-1337 https://doi.org/10.1890/08-0741.1.

Janzen, D. 1988. Tropical dry forest: the most endangered major tropical ecosystem. In Biodiversity, ed. E.O. Wilson, 130-137. Washington, D.C: National Academy Press.

Jolly, W.M., M.A. Cochrane, P.H. Freeborn, Z.A. Holden, T.J. Brown, G.J. Williamson, and D.M. Bowman. 2015. Climate-induced variations in global wildfire danger from 1979 to 2013. Nature Communications 6: art.7537. https://doi.org/10. 1038/ncomms8537.

Liogier, A.H. 1994. Descriptive flora of Puerto Rico and adjacent islands (Vol. 3), 306-337. Rio Piedras: La Editorial, University of Puerto Rico.

Méndez-Tejeda, R., M. Santos-Corrada, S. Ortiz-Morales, and O. Claudio-Vargas. 2015. Environmental and economic impact of Forest fires in Puerto Rico 2013-2014. Open Journal of Forestry 5: 353-363 https://doi.org/10.4236/ojf.2015.54030.

Miles, L., A.C. Newton, R.S. DeFries, C. Ravilious, I. May, S. Blyth, V. Kapos, and J.E. Gordon. 2006. A global overview of the conservation status of tropical dry forests. Journal of Biogeography 33: 491-505. https://doi.org/10.1111/j.13652699.2005.01424.x.

Monmany, A.C., W.A. Gould, M.J. Andrade-Núñez, G. González, and M. Quiñones. 2017. Characterizing Predictability of Fire Occurrence in Tropical Forests and Grasslands: The Case of Puerto Rico. In Forest Ecology and Conservation, ed. S. Chakravarty and G. Shukla, 77-95. InTech. https://doi.org/10.5772/67667.

Monsegur Rivera, O.A. 2009. Vascular flora of the Guánica Dry Forest, Puerto Rico, 205. Mayagüez: (Master's Thesis) University of Puerto Rico, Mayagüez Campus.

Moreno, L.M., E. Meléndez-Ackerman, C. Cheleuitte, L. Lastra, R. Rodríguez, and J. Rojas-Sandoval. 2014. Potential impacts of the invasive grass Megathyrsus maximus (Poaceae) on ground-dwelling arthropods in a Caribbean dry forest. Caribbean Naturalist 7: 1-15.

Murphy, P.G., and A.E. Lugo. 1995. Dry forests of Central America and the Caribbean. In Seasonally dry tropical forests, ed. S.H. Bullock, H.A. Mooney, and E. Medina, Cambridge: Cambridge University Press, 9-34. https://doi.org/10. 1017/CBO9780511753398.002

Murphy, P.G., A.E. Lugo, A.J. Murphy, and D.C. Nepstad. 1995. The dry forests of Puerto Rico's south coast. In Tropical forests: management and ecology, 178209. New York: Springer https://doi.org/10.1007/978-1-4612-2498-3_7.

R Core Team. 2016. R: A language and environment for statistical computing. Vienna: R Foundation for Statistical Computing URL https://www.R-project.org/.

Rojas-Sandoval, J., and E. Meléndez-Ackerman. 2012. Effects of an invasive grass on the demography of the Caribbean cactus Harrisia portoricensis: implications for cacti conservation. Acta Oecologica 41: 30-38 https://doi.org/ 10.1016/j.actao.2012.04.004.

Rojas-Sandoval, J., E. Meléndez-Ackerman, and D.S. Fernández. 2012. Plant community dynamics of a tropical semi-arid system following experimental removals of an exotic grass. Applied Vegetation Science 15: 513-524 https://doi.org/10.1111/j.1654-109X.2012.01199.x

Rojas-Sandoval, J., E.J. Meléndez-Ackerman, and D. Anglés-Alcázar. 2016. Assessing the impact of grass invasion on the population dynamics of a threatened Caribbean dry forest cactus. Biological Conservation 196: 156-164 https://doi.org/10.1016/j.biocon.2016.02.015.

Santiago-García, R.J., S. Molina-Colón, P. Sollins, and S.J. Van Bloem. 2008. The role of nurse trees in mitigating fire effects on tropical dry forest restoration: a case study. Ambio: A Journal of the Human Environment 37 (7): 604-608 https://doi.org/10.1579/0044-7447-37.7.604.

Thaxton, J.M., S. Cordell, R.J. Cabin, and D.R. Sandquist. 2012a. Non-native grass removal and shade increase soil moisture and seedling performance during Hawaiian dry forest restoration. Restoration Ecology 20 (4): 475-482 https:// doi.org/10.1111/j.1526-100X.2011.00793.x.

Thaxton, J.M., S.J. Van Bloem, and S. Whitmire. 2012b. Fuel condition associated with native and exotic grasses in a subtropical dry forest in Puerto Rico. Fire Ecology 8 (3): 9-17. https://doi.org/10.4996/fireecology.0803009.

Thomas, K.A., C.J. Jarchow, and J.A. Crawford. 2017. Survival of the endangered pima pineapple cactus: does clearing before prescribed fire alter survival postfire? The Southwestern Naturalist 62 (3): 200-206 https://doi.org/10.1894/ 0038-4909-62.3.200

Thomas, P.A. 1991. Response of succulents to fire: a review. International Journal of Wildland Fire 1 (1): 11-22 https://doi.org/10.1071/WF9910011.

Thomas, P.A. 2006. Mortality over 16 years of cacti in a burnt desert grassland. Plant Ecology 183 (1): 9-17 https://doi.org/10.1007/s11258-005-9001-7. 
Thomas, P.A., and P. Goodson. 1992. Conservation of succulents in desert grasslands managed by fire. Biological Conservation 60 (2): 91-100 https://doi.org/10.1016/0006-3207(92)91159-P.

U.S. Fish and Wildlife Services. 1990. Endangered and threatened wildlife and plant: Rules and regulations. Determination of threatened status for the plant Harrisia portoricensis (Higo chumbo). Federal Registry 55: 32252-32255.

Valiente-Banuet, A., M.C. Arizmendi, A. Rojas-Martínez, H. Godínez-Álvarez, C. Silva, and P. Dávila-Aranda. 2002. Biotic interactions and population dynamics of columnar cacti. In Columnar Cacti and their Mutualists: Evolution, Ecology, and Conservation, ed. T.H. Fleming and A. Valiente-Banuet, 225-240. Tucson: University of Arizona Press.

Van Beusekom, A.E., W.A. Gould, A.C. Monmany, A.H. Khalyani, M. Quiñones, S.J. Fain, M.J. Andrade-Núñez, and G. González. 2018. Fire weather and likelihood: characterizing climate space for fire occurrence and extent in Puerto Rico. Climatic Change 146 (1-2): 117-131 https://doi.org/10.1007/s10584-017-2045-6.

Vermeire, L.T., and A.D. Roth. 2011. Plains prickly pear response to fire: effects of fuel load, heat, fire weather, and donor site soil. Rangeland Ecology \& Management 64 (4): 404-413 https://doi.org/10.2111/REM-D-10-00172.1.

Walker, L.R., and W. Boneta. 1995. Plant and soil responses to fire on a ferncovered landslide in Puerto Rico. Journal of Tropical Ecology 11 (3): 473-479 https://doi.org/10.1017/S0266467400008981.

Weaver, P.L., and J.J. Schwagerl. 2008. Secondary forest succession and tree planting at the Laguna Cartagena and Cabo Rojo Wildlife Refuges in southwestern Puerto Rico. Ambio: A Journal of the Human Environment 37 (7): 598-603 https://doi.org/10.1579/0044-7447-37.7.598.

Wolfe, B.T., G.E. Saldaña Diaz, and S.J. Van Bloem. 2014. Fire resistance in a Caribbean dry forest: inferences from the allometry of bark thickness. Journal of Tropical Ecology 30 (02): 133-142 https://doi.org/10.1017/ S0266467413000904.

Wolfe, B.T., and S.J. Van Bloem. 2012. Subtropical dry forest regeneration in grassinvaded areas of Puerto Rico: understanding why Leucaena leucocephala dominates and native species fail. Forest Ecology and Management 267: 253261 https://doi.org/10.1016/j.foreco.2011.12.015.

\section{Publisher's Note}

Springer Nature remains neutral with regard to jurisdictional claims in published maps and institutional affiliations.

\section{Submit your manuscript to a SpringerOpen ${ }^{\circ}$ journal and benefit from:}

- Convenient online submission

- Rigorous peer review

- Open access: articles freely available online

- High visibility within the field

- Retaining the copyright to your article

Submit your next manuscript at $\boldsymbol{\nabla}$ springeropen.com 